\title{
Natural Disasters and the Development of Chinese History
}

\author{
ZHAO Xiaohua*
}

\section{The Relation of Severe Natural Disasters to Political and Social life}

Natural disasters are the common enemy of all human beings, who have tenaciously struggled against all kinds of natural disasters to develop themselves. China has always been dogged by disasters, owing to its vast territory, complex geographical conditions, and varying climatic conditions. Contemporary disaster-science researchers in China believe that there have been four major periods of disasters in China's history, namely, the Xia Yu Cosmic Period 夏禹宇宙期, Two Hans Cosmic Period 两汉宇宙期, Ming-Qing Cosmic Period 明清宇宙期, and Late Qing Cosmic Period 清末宇宙期. ${ }^{1}$ The first period, the Xia Yu Cosmic Period, also known as Xia Yu Flood Period 夏禹洪水期, spanned about 400 years roughly from 2010 to 1610 BCE. According to records in the pre-Qin literature, the legendary King Yu 禹王 tamed the floods in this period. The important environmental changes in the late Neolithic Period have become a focal point of research on early Chinese civilization. According to one study by Chinese scholars, "A series of geological, meteorological, astronomical, and cultural anomalies reveal that the period around 2000 BCE was a period of cooling, great floods, earthquakes, and a great cultural shift in the context of astronomical anomalies. All this indubitably confirmed that the Xia Yu Flood Period around 4,000 years ago was a period of concurrent natural disasters, as well as an abnormal period in the history of Chinese culture and an important cultural fault and

* Zhao Xiaohua 赵晓华 is a professor in the School of Humanities, China University of Political Science and Law.

1 Xia Mingfang 夏明方, “The Historical Conditions for the Early Modernization of China as Seen from the Period of Concurrent Natural Disasters in the Late Qing Dynasty: Research on Disasters and the Westernization Movement”从清末灾害群发 期看中国早期现代化的历史条件: 灾荒与洋务运动研究之一, Qingshi yanjiu 清史研究, 1998, no. 1 . 
shift."2 In addition, the Two Hans Cosmic Period lasted 400 years from 200 $\mathrm{BCE}$ to $200 \mathrm{CE}$; the Ming-Qing Cosmic Period, 200 years from 1500 to 1700; and the Late Qing Cosmic Period over 100 years from 1810 to 1911. Western scholars such as D. M. Mallong and A. Hosie, and Chinese scholars such as Zhu Kezhen 竺可楨, Chen Da 陳達, and Deng Tuo 鄧拓, have reviewed studies on the frequency of natural disasters in China's history. According to Deng Tuo's incomplete statistics, there were 5,258 natural disastersincluding floods, droughts, locust swarms, hail, wind, epidemics, earthquakes, frosts, and snow-during the 3,703 years from $1766 \mathrm{BCE}$ to $1937 \mathrm{CE} .{ }^{3}$ Among the various disasters, floods and droughts accounted for the biggest percentage: "According to written records, almost every year witnessed a big flood or drought during the 2,155 years from 206 BCE to 1949 CE."4 The Western scholar Walter H. Mallory called China the "land of famine" in the subtitle to his book. ${ }^{5}$ The Chinese economic historian Fu Zhufu 傅筑夫 pointed out, "The Twenty-Four Histories can almost be regarded as a chronicle of disaster and famine. There are frequent occurrences of floods, droughts, plagues of insects and locusts, and other natural disasters, and the histories describe these disasters and famines at great length." 6

Chinese history has often been characterized as having "a disaster every year and famine everywhere." Frequent disasters of long duration-like floods, droughts, and locust plagues - span a wide area on a large scale, and thus cause huge loss of life and property. According to statistics, in Chinese history from the Western Han Dynasty (206 BCE-8 CE) to the Opium War (1839-1842), there were 144 major climatic disasters each responsible for a loss of over 10,000 lives. If we add earthquakes of this magnitude, there have been at least 160 disasters. During the Ming and Qing Dynasties, large numbers of people died of drought, hail, frost, tides, landslides, earthquakes, and other disasters. The Ming Dynasty witnessed 370 disasters with 6,274,502 deaths, and the Qing Dynasty 413 disasters with 51,351,547 deaths, for a total of 783 disasters and more than 57,626,000 deaths during

2 Hao Ping 郝平 and Gao Jianguo 高建国, On Disasters and Social Change in North China from a Multidisciplinary Perspective 多学科视野下的华北灾荒与社会变迁研究 (Taiyuan: Beiyue Wenyi Chubanshe, 2010), p.41.

3 Deng Tuo 邓拓, The History of Disaster Relief in China 中国救荒史 (Beijing: Beijing Chubanshe, 1998), p.53.

4 People’s Daily 人民日报, March 14, 1990.

5 Walter H. Mallory, China: Land of Famine (New York: American Geographical Society, 1926).

6 Fu Zhufu 傅筑夫 et al., China Economic History Data 中国经济史资料, Qin, Han, Three Kingdoms vol. 秦汉三国编 (Beijing: Zhongguo Shehui Kexue Chubanshe, 1982), p. 96. 
the two dynasties. ${ }^{7}$ In addition, various natural disasters led to arid lands, crop failures, population migrations, and deterioration of ecological environments, all of which severely restricted the development of agricultural production.

Severe natural disasters also threatened social stability and feudal rule. According to statistics, of 13 large-scale peasant uprisings in premodern China, 12 broke out partly because of natural disasters (mostly floods, droughts, and insect infestations), of which 8 directly weakened or even led to the collapse of the dynasty in power. ${ }^{8}$ Natural disasters and related manmade disasters were important causes of regime change. History is littered with examples of dynastic decline induced by such disasters. In the Western Han Dynasty, natural disasters were already rampant, but by the end of Wang Mang's Xin Dynasty (9-23 CE), "droughts year after year left people in poverty and forced them to resort to stealing." 9 In 611, the seventh year of Emperor Yang of the Sui Dynasty, floods in Shandong and Henan inundated more than 30 counties, and officials also seized property from ordinary people. As a result, commoners were forced to rise up against the Sui Dynasty. In 874, the first year of Emperor Xizong of the Tang Dynasty, severe drought and locust plagues caused Wang Xianzhi 王仙芝 and Huang Chao 黄巢 to led a peasant uprising. Those affected by the disasters could barely survive, but local officials failed to relieve them. Moreover, "officials hid the situation from the Emperor and left the people suffering from hunger, so people formed gangs of thieves and caused trouble wherever they went." The Huang Chao Uprising was eventually suppressed, but the Tang Dynasty was about to collapse. By the end of the Tang Dynasty, "in the city, people ate each other, and fathers ate sons; while the Emperor ate porridge, others in the Imperial Palace often starved to death." 10 In the late Ming Dynasty (1368-1644), there were consecutive great droughts, locust plagues, and epidemic diseases in Zhili, Henan, Shandong, Shanxi, Shaanxi, Gansu, Zhejiang, and Jiangsu. The afflicted areas presented a scene of utter desolation, and the bodies of the starved were everywhere, when famine victims “formed gangs of thieves." Finally, the great Li Zicheng 李自成 uprising

7 Chen Yuqiong 陈玉琼, Gao Jianguo 高建国, “Time Characteristics of Major Climatic Disasters Responsible for the Loss of over 10,000 Lives in Chinese History" 中国历 史上死亡一万人以上的重大气候灾害的时间特征, Daziran tansuo 大自然探索, 1984, no. 4. Gao Jianguo 高建国, “A Study of Basic Parameters of Natural Disasters, Part 1" 自然灾害基本参数研究 (一), Zaihaixue 灾害学, 1994, no. 4.

8 He Zhiqing 赫治清, A Study of the History of Disasters in Premodern China 中国古 代灾害史研究 (Beijing: Zhongguo Shehui Kexue Chubanshe, 2007), p. 473.

9 Ban Gu 班固, “Wang Mang” 王莽傳, in the Book of Han 漢書, vol. 99 (Beijing: Zhonghua Shuju, 1990).

10 Ouyang Xiu 欧阳修, “Food and Goods, Part 2” 食貨志二, in Xin Tang Shu 新唐書 (New Book of Tang), vol. 52 (Beijing: Zhonghua Shuju, 1975). 
broke out. Before the Revolution of 1911, the whole country was stricken by disasters. From 1904, the thirtieth year of Emperor Guangxu, to 1910, the second year of Emperor Xuantong, there were severe floods in Hubei, Hunan, and other provinces for seven consecutive years, with a few areas suffering from severe droughts. In 1911 floods were still raging in the middle and lower reaches of the Yangtze River. In Hubei, Hunan, Jiangsu, Anhui, Zhejiang, and Jiangxi, rain poured down in torrents in the summertime and drowned fields and farmhouses. In the famine years, people became destitute and homeless, and their misery drove them to plunder around for rice. In this context, the Wuchang Uprising 武昌起義 led to the Revolution of 1911, which quickly swept the country.

\section{Disaster Relief in Chinese History}

In the long struggle against natural disasters, the Chinese have gained a deep understanding of disasters and have summarized their experience in a series of lessons in disaster prevention, disaster mitigation, and disaster relief. In the Book of Rites 禮記, "Proceedings of Government in the Different Months" 月令, it is said that the government provides relief for shortages in the second month of spring. It can thus be seen that the Chinese, when faced with disasters, were concerned about relief from an early age. For example, King Yu tamed the flood during the transition period between the late Longshan Culture 龍山文化 and the early Erlitou Culture 二里頭文化, when serious flooding occurred in the middle and lower reaches of the Yellow River. King Yu developed a scientific flood control scheme through field survey and measurements, and took the lead in taming floods. After thirteen years of efforts, he finally succeeded in controlling floods. The Great Yu's success in flood control indicates that the ancient Chinese had certain abilities to resist natural disasters. In ancient Chinese society, famine-relief-related laws, institutions, policies, and measures were collectively referred to as the Famine Policy 荒政. The twelve items of famine policy listed in the Rites of Zhou 周禮, “Grand Minister of Land and People" 大司徒, have long been regarded as criteria for disaster relief.11 The Qing Dynasty, China's last feudal dynasty, absorbed the essence of previous relief systems. In the Collected Statutes 會典 of both the Qianlong and Jiaqing reigns, the twelve items of

11 These twelve items of famine policy are distributing resources 散利, reducing levies 薄征, suspending punishments 緩刑, relaxing corvée labor 弛力, removing prohibitions on hunting 舍禁, eliminating tariffs 去幾, diminishing the number of rituals 頶 禮, simplifying mourning for the dead 殺哀, putting away music instruments 蕃樂, taking measures to increase marriages 多昏, praying to the gods 索鬼神, and ridding society of thieves 除盗賊. 
famine policy were adjusted and reinterpreted. ${ }^{12}$ By absorbing the experience of past dynasties, the Qing Dynasty established a fairly complete system of disaster relief. In what follows, I will briefly introduce the traditional system of relief, with the Qing Dynasty system as an example.

The relief system in the Qing Dynasty had many aspects: disaster reports, disaster surveys, raising funds for relief, disaster relief, and so on. Disaster reports 報災, the first step of the relief system, involved reporting the circumstances of the disaster up through the bureaucracy. In 1660, the seventeenth year of Emperor Shunzhi, the court explicitly stipulated the deadlines for disaster reports: for disasters in the provinces directly administered by the court, circumstances should be reported first; for disasters in summer, the deadline was the end of the lunar sixth month; for disasters in autumn, the deadline was the end of the lunar ninth month. Disaster survey 勘災 involved local officials' investigating the severity of disasters and determining the corresponding disaster scores. The surveys served as an important basis for determining disaster scores and the amount of relief. In the Qing Dynasty, disasters were divided into ten grades of severity, with scores from six to ten defined as a disaster. In 1728, the sixth year of Emperor Yongzheng, the court stipulated that disaster surveys should be finished within 45 days. If local officials exceeded the time limit by half a month to over three months, they were punished according to the number of days overdue. ${ }^{13}$ In the process of disaster relief, raising funds for relief 籌賑 was a crucial step. Thus, Qing governments gradually established and improved the system for raising relief funds. In the Qing Dynasty, relief funds came mainly from the imperial-court allocation, province and county assistance, and local collections. In addition, individual donations, such as payments for official titles, were encouraged. In the early Qing period, the imperial-court allocation was the primary source of disaster relief. In the late Qing, individual donations became the main source of disaster relief because the central government was financially exhausted. Disaster relief 賑災 included tax exemptions, delay of the imposition of taxes, government relief, commodity-price controls, work relief, and pacification of displaced victims. The policy on tax exemptions 災镯 was that victims paid no taxes or less tax in the event of a natural disaster. In 1728, the sixth year

12 For example, the Collected Statutes of the Jiaqing Reign 嘉慶會典 adjusted the twelve items to preparing for famine relief 備䘲, killing pests 除撉, rescuing from disasters 救災, providing relief supplies 發賑, reducing the selling of grain 減䊮, providing loans 出貸, allowing tax exemptions 端賦, delaying the imposition of taxes 緩征, facilitating commerce 通商, encouraging donations 勸輸, encouraging reconstruction 興工築, and resettling displaced victims 集流亡.

13 Collected Statutes and Precedents of the Qing Dynasty 大清會典事例 (Beijing: Zhonghua Shuju, 1990), vol.288, pp.366-367. 
of Emperor Yongzheng, proportions of tax exemptions were specified as follows: "victims of ten-score disasters enjoy a 70-percent tax exemption; victims of nine-score disasters a 60-percent tax exemption; victims of eightscore disasters a 40-percent tax exemption; victims of seven-score disasters a 20-percent tax exemption; and victims of six-score disasters a 10-percent tax exemption." 14 In 1738, the third year of Emperor Qianlong, it was added that "victims of five-score disasters can also report disasters and enjoy a 10-percent tax exemption upon completion of the survey by local officials." 15 Delay of the imposition of taxes 緩征 involves postponing the imposition of taxes due in afflicted areas. Sometimes imposition was delayed until the ripening of wheat or the harvest in autumn. Sometimes taxes were imposed every two or three or five years. Government relief 賑濟 involved the government's dispensing food, funds, and other supplies for free to help victims through immediate difficulties. The relief might take the form of food, funds, or cooked porridge. Commodity-price controls 平䊮 involved stabilizing grain prices in afflicted areas. Famine or crop failure was often accompanied by high prices for rice. To relieve disaster victims, the government would stabilize prices by storing rice, sending rice by canal, purchasing rice, and the like. Work relief 以工代賑 involved relieving people in disaster areas by giving them employment in civil-works projects. Relief work projects mainly included repair of city walls; construction of river embankments, roads, and bridges; and renovation of houses and temples. The Qing Dynasty attached great importance to the pacification of victims 安輯. The government accomplished this in two major ways: resettlement and rehabilitation. Resettlement involved local governments' accepting and settling famine refugees, relieving them with food and sheltering them in modest housing. Rehabilitation involved local officials' returning famine refugees to their hometowns in early spring and aiding them to ensure spring plowing.

Besides the system of disaster relief, China also established systems of disaster prevention and mitigation down through the dynasties. For example, there were systems for storing grain against natural disasters. The most basic form was the Ever Normal Granary 常平倉, created in the Western Han Dynasty (206 BCE-8 CE) and followed by later generations. An official institution, Ever Normal Granaries were set up in the administrative cities of provinces and districts. In addition, private Public Welfare Granaries 義倉 were established in small cities and towns, and private Charitable Granaries 社倉 were founded in villages. These three sorts of granaries constituted a

14 Collected Statutes and Precedents of the Qing Dynasty 大清會典事例, vol.288, p. 369.

15 Veritable Records of the Qianlong Reign 清高宗實錄 (Beijing: Zhonghua Shuju, 1986), vol. 68, p. 102. 
complete storage network. Another example of disaster prevention and mitigation is that owing to frequent floods and droughts, premodern Chinese governments had their own water policies, such as irrigation projects and flood control. Moreover, they also pursued afforestation and land reclamation.

In addition to establishing a complete and rigorous system of disaster relief, China kept a lot of historical data on natural disasters and relief measures throughout the dynasties. The leading American environmental historian John R. McNeill believes that if we limit ourselves to using written records to reconstruct the environmental history, most of the world cannot compared with China, because "in Africa, Oceania, America, and most of Asia, except for the most recent periods, historians who are interested in other periods must rely on the work of archaeologists, climatologists, geologists, geological morphologists, and so on," yet in China, "historians can play an important role." 16 The Chinese famine historian Xia Mingfang 夏明方 argued that McNeill was only half right, however. "Even from as late as The Spring and Autumn Annals 春秋, China's first systematic history book, China enjoys at least two thousand years of history in recording natural disasters. The huge amount, many types, long series, and strong continuity are enough to make these records unique and valuable in the data bank of world environmental history." 17 Relatively accurate records of natural disasters were first seen in the Book of Han 漢書, “The Five Elements” 五行志. After that, official histories all followed its style to record various catastrophic events. Even most local histories followed the style with great attention to recording natural disasters of all kinds. Moreover, a large amount of historical data on famines can also found in official records, documents, and books. Since the Song Dynasty (960-1279), groups of scholars have systematically summarized official and private disaster-relief measures and experience. These men of insight wrote these summaries in books, most of which were regarded as relief guides by later rulers, were repeatedly published, and were widely spread. These works have considerable academic value today for understanding the evolution of natural disasters in history and learning past lessons on disaster relief and mitigation.

16 John McNeill 約翰·麥克尼爾, China's Environmental History from a Global Perspective 由世界透視中國環境史, in Accumulations: Essays on China's Environmental History 積漸所至: 中國環境史論文集, vol.1, edited by Liu Cuirong 劉 翠溶 and Mark Elvin伊禁可 (Taipei: Zhongyang Yanjiu Yuan Jingji Yanjiusuo, 1995), pp. 53-54. English version: John McNeill, "China's Environmental History in World Perspective," in Sediments of Time: Environment and Society in Chinese History, edited by Mark Elvin and Ts'ui-jung Liu (New York: Cambridge University Press, 1998), pp.31-52.

17 Xia Mingfang 夏明方, “Inhuman Tendencies in the Study of the History of Disaster in China” 中国灾害史研究的非人文化倾向, Shixue yuekan 史学月刊, 2004, no. 3 . 


\section{Research on the History of Disasters of China}

In modern China, research on the history of disasters began in the 1920s and 1930s. Zhu Kezhen 筑可楨 earlier explained the history of famines with modern science and in particular explored the development of disasters from the perspective of natural science. In 1928 Zhu Kezhen published a paper titled "The Geographical Environment and Floods in Zhili during the Qing Dynasty” 清直隸地理的環境與水災, the earliest paper about Qing famine history. ${ }^{18}$ Prior to 1949 Zhu Kezhen also wrote the most papers about famine history of any scholar. In 1937 Deng Tuo 鄧拓, at the age of 25, published The History of Disaster Relief in China 中國救荒史. This pathbreaking book was the first Chinese monograph to study disasters and relief ideas throughout Chinese history in a relatively complete, systematic, and scientific way. At the time, it was regarded as the best work about Chinese famine relief, as a work that "promoted the study of the Chinese history of famine to a new stage." 19 Also in the late 1930s, the scholar Pan Guangdan 潘光旦 analyzed the impact of disasters on the Chinese gene pool from the angle of eugenics in his book National Character and National Health 民族特性與民族 衛生, Jiang Jie 蔣傑 applied Malthus's theory of population to the demographic study of the Great Northwest Famine of 1928 in his Guanzhong Rural Population Problem 關中農村人口問題, and Chen Gaoyong 陳高庸 compiled A List of Natural and Manmade Disasters through Chinese History 中國歷代天災人禍表. ${ }^{20}$ From the foundation of the People's Republic of China in 1949 to the end of the Great Cultural Revolution, however, research about the history of disasters in the humanities and social sciences came almost to a standstill. ${ }^{21}$ Yet during that time, natural scientists from earthquake and water-conservation government agencies and research institutes, in the service of China's economic construction and disaster prevention and mitigation, fruitfully summarized a tremendous amount of historical data about natural

18 Zhu Kezhen 竺可楨, “The Geographical Environment and Floods in Zhili during the Qing Dynasty” 清直隸地理的環境與水災, Shixue yu dixue 史學與地學, 1928, no.3.

19 Li Wenhai 李文海 and Xia Mingfang 夏明方, “The Aspirations and Seminal Ideas of Deng Tuo's History of Disaster Relief in China” 邓拓〈中国救荒史〉研究的抱负与卓 见, Beijing ribao 北京日报, June 6, 2008.

20 Pan Guangdan 潘光旦, National Character and National Health 民族特性與民族衛生 (Shanghai: Shangwu Yinshuguan, 1937). Jiang Jie 蔣傑, Guanzhong Rural Population Problem 關中農村人口問題 (Yangling, Shaanxi: Guoli Xibei Nonglin Zhuanke Xuexiao 國立西北農林專科學校, 1938). Chen Gaoyong 陈高庸, A List of Natural and Manmade Disasters through Chinese History 中國歷代天災人禍表 (Shanghai: Guoli Jinan Daxue 上海国立暨南大学, 1939).

21 Zhu Hu 朱湤, "A Study of and Comments on the Qing History of Disasters in the Twentieth Century” 二十世纪清代灾荒史研究述评, Qingshi yanjiu 清史研究, 2003, no. 3. 
disasters, explored the evolution and spatial distribution of natural disasters in China, and made a mid- and long-term predictions about possible trends of future disasters. Since 1980s, the history of disasters, as a branch of social history, has made great strides. In this period, Li Wenhai 李文海 at Renmin University of China took the lead and founded the Natural Disasters Research Group. This group has published A Chronology of Modern China's Natural Disasters 近代中国灾荒纪年, Disasters and Famine: 1840-1919 灾荒与饥馑: 1840-1919, and other works. ${ }^{22}$ These findings broadened the research approach of the history of disasters by providing new data and developing new theoretical paradigms, and thus led a batch of scholars to engage in research in related fields. From the 1990s, a growing number of researchers entered the field of the history of disasters and published a variety of notable research outcomes. As a result, this discipline has gradually developed a distinct theoretical framework, fleshed out its academic content, and backed up its findings with ample historical data. The joint efforts of natural scientists and historians has led to the discovery and review of related historical records. These efforts led to four milestone publications in the history of disasters in China: A Chronology of Chinese Seismic Data 中国地震资料年表 (1956), the Qing River Flooding Historical Records Series 清代江河洪涝档案 史料丛书 (from 1988), A Distribution Atlas of Droughts and Floods in the Past 500 Years in China 中国近五百年旱涝分布图集 (1981), and China's Famine Relief Integration 中国荒政书集成 (2010). The last work, a collection of 185 famine relief documents in Chinese history totaling nearly 13 million Chinese characters, is the world's first systematic, complete compilation of Chinese famine-policy data. This book gives a general picture of Chinese faminerelief thought and practices from the pre-Qin period to the late Qing Dynasty, a time span of over two thousand years. Owing to the efforts of generations of scholars, research in the history of disasters in China has gradually expanded, penetrated deeper, and created a broader space for development.

In the twenty-first century, global destruction of the environment has created a need for research on the relationship between man and nature, including the history of natural disasters. This need will inevitably become a

22 Li Wenhai 李文海, Lin Dunkui 林敦奎, Zhou Yuan 周源, and Gong Ming 宫明, A Chronology of Modern China's Natural Disasters 近代中国灾荒纪年 (Changsha: Hunan Jiaoyu Chubanshe, 1990). Li Wenhai 李文海, Lin Dunkui 林敦奎, Cheng Xiao 程藏, and Gong Ming 宫明, A Continuation of a Chronology of Modern China's Natural Disasters 中国近代灾荒纪年续编 (Changsha: Hunan Jiaoyu Chubanshe, 1993). Li Wenhai 李文海 and Zhou Yuan 周源, Disasters and Famines: 1840-1919 灾荒与饥馑:1840-1919 (Beijing: Gaodeng Jiaoyu Chubanshe, 1991). Li Wenhai 李 文海, Cheng Xiao 程苇, Liu Yangdong 刘仰东, and Xia Mingfang 夏明方, Modern China's Top Ten Disasters 中国近代十大灾荒 (Shanghai: Shanghai Renmin Chubanshe, 1994). 
powerful driving force for further research. I truly believe that research on the history of disasters will continue to develop and produce significant academic results. 